Acta vet. scand. $1977,18,501-508$.

From the Department of Animal Hygiene, College of Veterinary Medicine, Animal Science Centre, Swedish University of Agricultural Sciences, Uppsala, Sweden.

\title{
DIFFERENT TISSUE UPTAKE AFTER ADMINISTRATION OF PROLINE AND HYDROXYPROLINE IN NEONATAL PIGLETS*
}

\author{
By
}

Gösta Bengtsson and Juhani Hakkarainen

\begin{abstract}
BENGTSSON, G. and J. HAKKARAINEN: Different tissue uptake after administration of proline and hydroxyproline in neonatal piglets. Acta vet. scand. 1977, 18, 501-508. - Using whole body autoradiography and impulse counting technique, distribution of intramuscularly administered ${ }^{14} \mathrm{C}$-DL-hydroxyproline and ${ }^{14} \mathrm{C}-\mathrm{L}$-proline in newborn piglets was compared. The main excretion route of hydroxyproline was via the kidneys. Hydroxyproline or its metabolic products were excreted at quite another rate by the liver than was proline. Skeletal muscles and myocardium showed a lowered ratio of proline to hydroxyproline. A difference in favour of hydroxyproline in passing the blood-brain barrier was shown. Contrary to proline hydroxyproline yielded a low ${ }^{14} \mathrm{C}$-level in the skeletal tissues. The possibilities of an incomplete hydroxylation of proline as an aetiological factor in the origin of skeletal disorders are discussed.
\end{abstract}

${ }^{14} \mathrm{C}-\mathrm{D}$ L-hydrox y proline; ${ }^{14} \mathrm{C}-\mathrm{L}-\mathrm{proline}$; a t oradiography; impulse counting; pigs.

After intramuscular injection of ${ }^{14} \mathrm{C}$-proline in neonatal piglets, the skeletal tissue showed a specific uptake of radioactivity as revealed by autoradiography (Bengtsson \& Hakkarainen 1975). The distinct localization in the metaphysis, periosteal layers and articular areas of the long bones was assumed to represent synthesis of bone matrix protein. From this accumulation of ${ }^{14} \mathrm{C}$ arose the question of the role of an insufficient supply of amino acids in the origin of skeletal disorders.

* This study was supported by grants from AB Lactamin-SLR, Sweden, and the Swedish Council for Forestry and Agricultural Research. 
The major part of the organic matter making up the skeletal system consists of collagen (Tonna 1965). Hydroxyproline is a specific amino acid residue of this protein (Barnes 1969). In the present work, tissue uptake (of skeletal tissue in particular) was studied in newborn piglets after administration of ${ }^{14} \mathrm{C}$-hydroxyproline. The distribution pictures after intramuscular injection of proline and hydroxyproline, respectively, were compared.

\section{MATERIAL AND METHODS}

\section{Radioactive material}

$2-{ }^{14} \mathrm{C}$-DL-hydroxyproline was obtained from the Radiochemical Centre, Amersham, England. The specific activity was 90 $\mu \mathrm{Ci} / \mathrm{mg}$ hydroxyproline. The radiochemical purity tested by thin layer chromatography was $99 \%$. The $2-{ }^{14} \mathrm{C}-\mathrm{L}-\mathrm{hyd}$ roxyproline content was reported to be $48 \%$ according to dilution analysis. ${ }^{14} \mathrm{C}(\mathrm{U})$-labelled L-proline was obtained and tested as described previously (Bengtsson \& Hakkarainen 1975).

\section{Whole body autoradiography}

At birth, male and female Swedish Landrace piglets were each given $70 \mu \mathrm{Ci}{ }^{14} \mathrm{C}$-hydroxyproline per $\mathrm{kg}$ body weight by intramuscular injection in the neck. The amino acid was dissolved in saline, giving a sterile solution containing $35 \mu \mathrm{Ci} / \mathrm{ml}$. ${ }^{14} \mathrm{C}$-L-proline was given to another group of piglets as described earlier (Bengtsson \& Hakkarainen). The subsequent procedure was as reported previously.

\section{Quantitative determinations}

Visual reading of the autoradiograms and quantitative determination on sections and organs, tissues and fluids after administration of proline and hydroxyproline was made as in previous work (Bengtsson \& Hakkarainen). The same amount of radioactivity $(60,000 \pm 4 \% \mathrm{CPM} / \mathrm{g}$ body weight $)$ was given as proline and hydroxyproline, respectively.

\section{RESULTS}

The distribution picture in the intact piglet $4 \mathrm{hrs}$. after intramuscular injection of ${ }^{14} \mathrm{C}$-hydroxyproline can be seen in Fig. 1. The relative percentage of the isotope in different organs as com- 
T a b l e 1. Radioactivity in tissues of newborn piglets $4 \mathrm{hrs}$. after intramuscular injection of ${ }^{14} \mathrm{C}$-L-proline (A) and ${ }^{14} \mathrm{C}$-DL-hydroxyproline (B), $10^{-3} \times \mathrm{CPM} / \mathrm{g}$ wet weight; each value represents the mean for two piglets.

\begin{tabular}{lrrc}
\hline Tissue & A & B & Ratio A/B \\
\hline Cerebrum & 6.9 & 26.2 & 0.26 \\
Cerebellum & 7.5 & 26.3 & 0.28 \\
Medulla oblongata & 6.7 & 18.0 & 0.37 \\
Skeletal muscle & 54.2 & 42.7 & 1.26 \\
Myocardium & 63.7 & 51.2 & 1.24 \\
Lymph gland & 57.0 & 28.6 & 1.99 \\
Thymus & 52.9 & 42.2 & 1.25 \\
Spleen & 69.8 & 23.6 & 2.95 \\
Adrenal & 55.1 & 23.7 & 2.32 \\
Thyroid & 38.2 & 18.5 & 2.06 \\
Hypophysis & 78.6 & 25.7 & 3.05 \\
Lung & 46.7 & 25.1 & 1.86 \\
Salivary gland & 79.4 & 32.5 & 2.44 \\
Pancreas & 106.9 & 45.0 & 2.37 \\
Liver & 102.1 & 41.5 & 2.46 \\
Kidney & 76.8 & 57.4 & 1.33 \\
Bile & 4.2 & 6.5 & 0.64 \\
Urine & 20.2 & 244.7 & 0.08 \\
\hline
\end{tabular}

pared to the liver is also given in the autoradiograms. Table 1 shows the absolute amounts of radioactivity per $\mathrm{g}$ tissue and fluid sampled from piglets 4 hrs. after injection of hydroxyproline and proline. It should be pointed out that sectioning was performed without the preceding bleeding while other piglets were exsanguinated when killed.

In the intact piglet (Fig. 1), the blood concentration of ${ }^{14} \mathrm{C}$ was about a quarter of that of the liver. In several organs, the level of radioactivity hardly exceeded that of the blood. Some organs, however, showed a distinct uptake. The highest concentration of ${ }^{14} \mathrm{C}$ was observed in the kidneys. The ${ }^{14} \mathrm{C}$-content of the myocardium, skeletal muscles, pancreas and thymus was of about the same magnitude as that of the liver. The uptake in the pancreas appeared to be confined mainly to the exocrine part. The ${ }^{14} \mathrm{C}$-content of the salivary gland was at a level between that of the liver and the blood. The brain, lungs, spleen, lymph glands and endocrine organs showed ${ }^{14} \mathrm{C}$-levels comparable to that of the blood. 
Fairly small amounts of radioactivity were found in the metaphysis and articular cartilages of the long bones. Still less uptake was observed in the periosteal layers of the bones and in the teeth. There was a moderate ${ }^{14} \mathrm{C}$-level in the cartilage, parti-
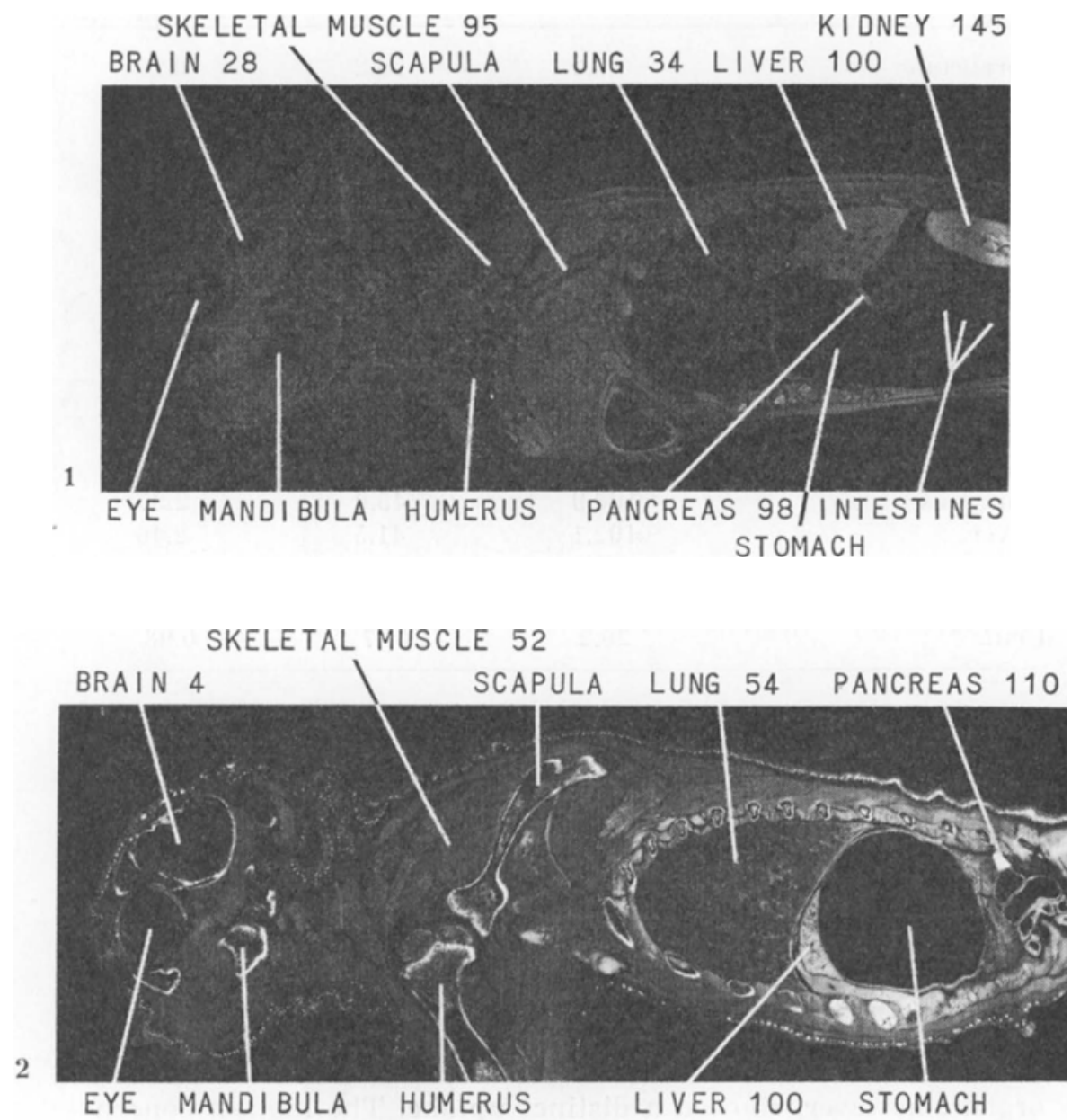

Figures 1 and 2. Autoradiograms of newborn piglets 4 hrs. after intramuscular injection of ${ }^{14} \mathrm{C}$-DL-hydroxyproline (Fig. 1) and ${ }^{14} \mathrm{C}-\mathrm{L}$ proline (Fig. 2). White areas correspond to high uptake of radioactivity. Numerals refer to CPM of corresponding dry section piece relative to the liver. Note high accumulation of ${ }^{14} \mathrm{C}$ in the bone tissues after administration of ${ }^{14} \mathrm{C}$-proline (Fig. 2), but not after ${ }^{14} \mathrm{C}$-hydroxyproline (Fig. 1). Pieces of bone were not sampled for ${ }^{14} \mathrm{C}$ counting owing to difficulties in obtaining relevant parts on the dried section. 
cularly that of the trachea. In the eye, the highest accumulation of radioactivity was found in the iris and the ciliary process, and was of the same order of size as that of the muscles.

A very high concentration of radioactivity was found in the urine $4 \mathrm{hrs}$. after the administration of ${ }^{14} \mathrm{C}$-hydroxyproline. The ${ }^{14} \mathrm{C}$-content of the bile was low, as was that of the wall and mucous membranes of the stomach and intestinal tract. Distinct localization of radioactivity was seen in the hair follicles.

\section{DISCUSSION}

The distribution picture in neonatal piglets after administration of ${ }^{14} \mathrm{C}$-hydroxyproline is fairly uniform, showing only a few striking features (Fig. 1). The picture will, however, be more interesting on comparison with that obtained after injection of ${ }^{14} \mathrm{C}$-proline which is shown in Fig. 2. Only the racemic DL-hydroxyproline was available at the time of the experiment. D-amino acids are, however, not present in proteins (Harper 1973). Half of the injected hydroxyproline was the L-amino acid, and in order to obtain comparable autoradiograms and exposure times, about twice the dose of the label was given as hydroxyproline than as proline.

In Table 1 , the absolute amounts of radioactivity per $\mathrm{g}$ tissue and fluid are compared $4 \mathrm{hrs}$. after administration of ${ }^{14} \mathrm{C}$-DLhydroxyproline and ${ }^{14} \mathrm{C}$-L-proline. The same amount of the isotope was given in both cases. Since the D-amino acid is not utilized by the body, the ratio between ${ }^{14} \mathrm{C}$ derived from proline and hydroxyproline, at equal tissue uptake of the two substances or their metabolites should be about two.

Hydroxyproline would not appear to be the source of carcass hydroxyproline (Stetten 1949), i.e. it is not utilized directly in protein synthesis. The fate of hydroxyproline should therefore be either through excretion or metabolism in different ways. Administration of ${ }^{14} \mathrm{C}$-proline yielded a higher ${ }^{14} \mathrm{C}$-content in the liver than did ${ }^{14} \mathrm{C}$-hydroxyproline. Since the latter produced three times the increase in ${ }^{14} \mathrm{C}$ in the bile than ${ }^{14} \mathrm{C}$-proline, it is apparent that both $\mathrm{D}$ - and L-hydroxyproline or its metabolic products are excreted to a large extent by the liver. The liver plays a major role in metabolism in general. The accumulation in this organ of ${ }^{14} \mathrm{C}$ derived from hydroxyproline should therefore represent intermediary metabolism of the amino acid. 
The high level of the marker found in the kidneys and the urine after injection of ${ }^{14} \mathrm{C}$-hydroxyproline denotes renal excretion. In the rat dietary hydroxyproline is largely excreted unchanged by the kidneys (Pedersen \& Lewis 1944). Therefore in the neonatal piglet, both the D- and L-amino acid should appear in the urine. Higher uptake in the thymus in favour of hydroxyproline could be related to intermediary products showing affinity to the gland rather than to specific metabolism in the thymocytes of the amino acid itself, or to phagocytosis of the D-label.

Both skeletal muscles and myocardium showed a lowered ratio of proline to hydroxyproline. In rats, radioactivity from $\mathrm{N}^{15}$-labelled dietary hydroxyproline was recovered widely in other amino acids, especially glutamic and aspartic acid (Stetten). Only about $0.1 \%$ of the carcass hydroxyproline became labelled. High concentration of ${ }^{14} \mathrm{C}$ derived from hydroxyproline in the muscles therefore should reflect intermediary metabolism of the amino acid also in the newborn pig. The difference in favour of hydroxyproline in passing the blood-brain barrier could indicate that metabolites of this amino acid, but not of proline, are utilized by the brain.

The greatest difference between the two amino acids studied concerns the skeletal uptake. Though hydroxyproline is a significant constituent of collagen (Eastoe 1955), according to the present study, bones are not target tissue for this amino acid in the developing pig. In the rat, proline is shown to be the precursor of collagen hydroxyproline (Stetten \& Schoenheimer 1944, Stetten). The high level of ${ }^{14} \mathrm{C}$ in the present study found in the metaphysis, periosteal layers and articular areas of the bones of the piglet after administration of ${ }^{14} \mathrm{C}$-proline, appears to represent hydroxyproline entirely or partly. ${ }^{14} \mathrm{C}$-proline-derived radioactivity appears rapidly in the bones (Bengtsson \& Hakkarainen 1975), indicating that the amino acid is hydroxylated within the bone and not in any other tissue.

The primary phase of bone formation is the synthesis of matricial proteins (Uitto \& Laitinen 1968), i.e. mainly collagen (Tonna 1965). Since hydroxylation of proline seems to be a very important step in collagen synthesis, the question rises of the significance of disturbances in this process for the origin of skeletal disorders. In the metabolism of collagen, ascorbic acid appears to be a co-factor in the hydroxylation of proline 
to hydroxyproline (Gould \& Woessner 1957, Robertson 1964). Moreover, as reviewed and reported by Barnes (1969), collagen synthesis takes place at a reduced rate in ascorbic acid deficiency. On the basis of earlier studies, domestic animals are known to be independent of an exogenous supply of vitamin C, owing to synthesis of this vitamin by the animal itself. However, modern technique has introduced new harvesting and processing methods for the food including heating, steaming, pelletting and so on. During these processes constituents or precursors of vitamin $C_{1}$ could be irreversibly inactivated or destroyed, yielding impaired prerequisites for ascorbic acid synthesis by the animal. As a consequence there is probably a reduced formation of collagen and hence of bone, resulting in an increased likelihood of skeletal disorders.

The small amounts of ${ }^{14} \mathrm{C}$ appearing in the skeleton and cartilages after adninistration of ${ }^{14} \mathrm{C}$-hydroxyproline most plausibly represent intermediary metabolites, preferably amino acids of the label as in the muscles. The same is probably true for ${ }^{14} \mathrm{C}$-activity in the eye. In the case of the salivary gland, the pancreas and the skin, radioactivity probably reflects both protein synthesis from intermediary amino acids and excretion.

\section{REFERENGES}

Barnes, M. J.: Nutritional Aspects of the Development of Bone and Connective Tissue. J. C. Somogyi and E. Kodicec, eds., Basel \& New York 1969.

Bengtsson, S. G. \& R. V. J. Hakkarainen: Distribution in piglets after administration of ${ }^{14} \mathrm{C}$-L-proline as studied by whole body autoradiography and impulse counting. J. Anim. Sci. 1975, 41, 106112.

Eastoe, J. E.: The amino acid composition of mammalian collagen and gelatin. Biochem. J. 1955, 61, 589-600.

Gould, B. S. \& J.F. Woessner: Biosynthesis of collagen. The influence of ascorbic acid on the proline, hydroxyproline, glycine, and collagen content of regenerating guinea pig skin. J. biol. Chem. 1957, 226, 289-300.

Harper, H. A.: Review of physiological chemistry, 14th Ed., Los Altos, California: Lange Medical Publications, 1973.

Pedersen, S. \& H. B. Lewis: The partition of urinary nitrogen after the oral administration of glutamic acid, pyrrolidone carboxylic acid, proline, and hydroxyproline to rabbits. J. biol. Chem. 1944, 154, 705-712.

Robertson, Wm van B.: Metabolism of collagen in mammalian tissues. Biophys. J. 1964, 4, Suppl. 1, 93-106. 
Stetten, M. R.: Some aspects of the metabolism of hydroxyproline, studied with the aid of isotopic nitrogen. J. biol. Chem. 1949, $181,31-37$.

Stetten, M. R. \& R. Schoenheimer: The metabolism of 1(-)-proline studied with the aid of deuterium and isotopic nitrogen. J. biol. Chem. 1944, 153, 113-132.

Tonna, E. A.: The Use of Radioactivity in Investigating Protein Synthesis. C. P. Leblond and K. B. Warren, eds., New York and London 1965.

Uitto, J. \& O. Laitinen: Relation of collagen metabolism to calcium metabolism in the bone. Acta chem. scand. 1968, 22, 10391040.

\section{SAMMANFATTNING}

Skillnader $i$ vävnadsupptag efter parenteral tillförsel av prolin och hydroxyprolin till nyfödda grisar.

En jämförande undersökning avseende vävnadsupptag och utsöndring har gjorts på nyfödda grisar efter injektion av ${ }^{14} \mathrm{C}$-märkt L-prolin och DL-hydroxyprolin. Autoradiografi på hela djur samt impulsräkning på vävnader, organ och kroppsvätskor har utförts. Huvuddelen av parenteralt tillfört hydroxyprolin elimineras renalt. DL-hydroxyprolin eller dess metaboliter utsöndras snabbare via levern än motsvarande från prolin härledda substanser. Av de båda aminosyrorna gav hydroxyprolin högre ${ }^{14} \mathrm{C}$-upptag $\mathrm{i}$ muskelvävnad och hjärnsubstans än prolin. Till skillnad från prolin visade hydroxyprolin låg affinitet till benvävnaden. Möjligheterna av en rubbning $i$ hydroxyleringen av prolin som orsak till vissa sjukdomar $i$ skelettet på husdjur diskuteras.

(Received June 27, 1977).

Reprints may be requested from: Gösta Bengtsson, the Department of Animal Hygiene, College of Veterinary Medicine, HVC, Swedish University of Agricultural Sciences, S-750 07 Uppsala, Sweden. 